Michael Hebbert

\title{
FROM CAMPUS LANDSCAPES TO KNOWLEDGE QUARTERS: HOW LEARNING RETURNED TO ITS URBAN ROOTS
}

\section{INTRODUCTION}

Two things are clear from the abundant literature on the design of universities. Firstly, it is rash to generalise. The world's regions operate on differing trajectories. Their universities vary enormously in size, shape and content. Each has its own narrative and geographical context. They are individuals. But, secondly, they are also historical actors, susceptible to social trends and the cultural Zeitgeist. University architecture embodies historical change.

Nowhere is this more evident than in the relationship between town and gown, campus and city. ${ }^{1}$ Historically, the nexus between

DOI: https://doi.org/10.12697/BJAH.2018.16.09

The following bear no responsibility for the contents of the paper, but their help in its preparation is most gratefully acknowledged: Laura A. Cruickshank (Yale University), Sue Donnelly (LSE), Victor Eskinazi (Sasaki Associates), James Hopkins (University of Manchester), Haruka Horiuchi (Rafael Viñoly Architects), Vittorio Magnago Lumpagnani (ETH Zürich), Juhan Maiste (University of Tartu), Juliana Martins (UCL), Gerhard Schimak (TUWien), Domenic Vitiello (University of Pennsylvania).

1 The University and the City: From Mediaeval Origins to the Present, ed. by Thomas Bender (New York: Oxford University Press, 1988); Peter Hall, 'The University and the City', Geojournal, 41 (4) (1997), 301-309; Philippe Genestier, 'L'Université et la Cité', L'Habitat des Étudiants en France, ed. by Philippe Genestier, Pierre Merlin, Joëlle Jacquin (Marne-la-Vallée: Laboratoire Théories des Mutations Urbaines, 1991), 1-45. 
cities and universities has run deep: their very names declare it. In the ancient settlements of Europe, the colleges and faculties were interspersed throughout the towns. The universities of the Enlightenment were set in urban parklands. In the late nineteenth century, American colleges were experimenting with new settings that were suburban or rural, in landscapes called campuses; ${ }^{2}$ however, the great civic universities and technical high schools of Europe stayed rooted in monumental public edifices on the city-centre intersections of tram-routes.

The history of the past hundred years can be read as a prolonged experiment of decoupling. Anti-urbanism was a pervasive aspect of the Modernist Zeitgeist. Art and architecture strove to escape the minerality of pavements and facades, views framed by building frontages, the promiscuity and density of urban life. Twentiethcentury transport and communications technologies offered escape routes to an idealised natural landscape. Entire programmes of university-building were premised on the acquisition of extensive green-field sites, including Governor Nelson Rockefeller's 63 campuses for the State University of New York, and the twelve or more new institutions in bucolic settings around Britain that are chronicled in Stephan Muthesius's Utopian Campuses ${ }^{3}$. The University Grants Commission in Great Britain believed that creative thinking was more likely to happen in spacious parklands. Committed to the image of a campus as an extensive landscape, it rejected pleas for investment in urban settings, and particularly in city centres: 'spaciousness in itself and a site unencumbered by industrial development were, it was argued, intrinsically advantageous for a university'. ${ }^{4}$ The cult of nature is well-illustrated in the heart of the industrial Ruhr. In 1968, Dortmund's new Technical University was located three kilometres outside of town, auf der grünen Wiese (in the green meadows), with a forest reserve traversed by a monorail separating the two halves of the campus. The campuses of French technical schools of the same

2 Paul V. Turner, Campus: An American Planning Tradition (Cambridge, MA: MIT Press, 1984).

3 Stephan Muthesius, The Postwar University: Utopianist Campus and College (New Haven: Yale University Press, 2001); Tony Birks, Building the New Universities (Newton Abbott: David \& Charles, 1972).

4 Peter Cowan, The University in an Urban Environment: a study of activity patterns from a planning viewpoint sponsored by the Centre of Environmental Studies (London: Heinemann, 1974), 23-25. 
vintage were less vehemently anti-urban, but, as Rosemary Wakeman puts it in her study of the Technopoles, they 'reduced urbanity to the ideal type of the garden suburb - a work and recreational paradise for engineers and scientists'. ${ }^{5}$

The numerous evacuations of existing establishments from the heart of cities such as Aalborg, Brussels, Oporto, Québec (Université Laval), and Stockholm were equally revealing of the anti-urbanism of the time. Pierre Merlin has documented how the French authorities responded to the student riots of 1968 with an extensive programme of dispersal to the banlieux ${ }^{6}$. In the British case, the requirements for staff parking may have been a stronger motive than the fear of student radicalism. In 1970 the urban planners in London assumed that the colleges that could, would want to relocate out of town in the coming era of full motorisation and personal mobility. ${ }^{7}$ Battersea College of Technology migrated to become the University of Surrey. The London School of Economics explored possible relocation from its dense cluster of centrally-located buildings to a 45 -acre greenfield site beyond Croydon, south of London - a proposal luckily rejected, thanks to academic democracy, by an overwhelming vote of the staff in May 1965. ${ }^{8}$ TUWein, the Technical University of Vienna, similarly declined to move from its historic base on the Ringstrasse to a campus located fifty kilometres away in Tulln.

The position of larger, older urban universities locked into their central locations was widely perceived as detrimental. Several made use of urban renewal programmes to expand their sites. When the streets and inner-city (i.e. generally low-income) homes had been cleared, the enlarged site of the campus was marked off by fences, blank walls or buffer plantings of shrubs and trees. Paradoxically the Modernist campus adopted the archaic scholarly settings of the cloister and precinct as the ideal, sequestering academics from

5 Rosemary Wakeman, 'Dreaming the New Atlantis: Science and the Planning of Technopolis 1955-1985', Osiris, 18 (1) (2003), 269.

6 Pierre Merlin, L'Urbanisme Universitaire à l'Étranger et en France (Paris: Presses de l'école Nationale des Ponts et Chaussées, 1995).

7 Greater London Development Plan Report of Studies (1970), see: Cowan, The University in an Urban Environment, 21.

8 Ralf Dahrendorf, LSE: A History of the London School of Economics and Political Science 1895-1995 (Oxford: Oxford University Press, 1995). 
the disorder of the civic realm: as Tom Kvan puts it, 'the pursuit of knowledge was framed as an inward mission'.

However, the campus ideal could prove disappointing in practice. Students interviewed for Peter Marris's study The Experience of High Education complained of the inconvenience and isolation of peripheral locations and the sense that they were 'cut off from the outside world'. ${ }^{10}$ It had been hoped that physical segregation would encourage collegiality, interdisciplinarity and a more holistic pursuit of knowledge. ${ }^{11}$ As it turned out, it had rather the opposite effect. Lower density meant lower levels of interaction and reinforced the conceptual segregation of disciplines within a 9-am-to-5-pm commuter environment. The powerful dynamic of academic specialisation found expression in building complexes dedicated to separate disciplines. Deans exerted a baronial sway over the campus territory.

So much for the last century. The millennium provides a convenient marker for the radical design shift that has turned the previous relationship between universities and cities on its head. An acute sense of entering a fresh Zeitgeist runs through the recent literature on campus design. ${ }^{12}$ In Urban Design for the Knowledge Society, Kerstin Hoeger of ETH Zürich draws examples from corporate campuses and technopoles, as well as from universities in inner-city and out-oftown locations. She discerns a common agenda in these laboratories of the new Denkkultur. ${ }^{13}$ Based on a similar range of examples, my paper will sketch the attributes of this agenda under three simple headings: connectivity, consolidation and hybridity.

9 Tom Kvan, 'Context', Future Campus: Design Quality in University Buildings, ed. by Ian Taylor (London: RIBA Publishing, 2016), 4-5.

10 Cowan, The University in an Urban Environment, 27-30.

11 Anthony Ossa-Richardson, 'The Idea of a University and its Concrete Form', The Physical University: Contours of Space and Place in Higher Education, ed. by Paul Temple (London, New York: Routledge, 2014), 159-181.

12 Jonathan Coulson, Paul Roberts, Isabelle Taylor, University Trends - Contemporary Campus Design (London, New York: Routledge, 2015); Jonathan Coulson, Paul Roberts, Isabelle Taylor, University Planning and Architecture: The Search for Perfection (London, New York: Routledge, 2015); Future Campus: Design Quality in University Buildings, ed. by Ian Taylor (London: RIBA Publishing, 2016).

13 Campus and the City - Urban Design for the Knowledge Society, ed. by Kerstin Hoeger, Kees Christiaanse (Zürich: GTA Verlag, 2007). 


\section{EXTERNAL CONNECTIVITY}

In his introduction to the Royal Institution of British Architects' recent guide to good practice in university design, Tom Kvan of the University of Melbourne highlights the change in attitude towards campus boundaries - designed for impenetrability in the last century, for connectivity today. ${ }^{14} \mathrm{He}$ cites the example of the area around the University of Pennsylvania campus in Philadelphia. Its history is wellknown. ${ }^{15}$ Half a century ago, when the university was threatening to relocate to suburban Chester County, the municipality offered it generous urban renewal powers to raze the adjacent Afro-American neighbourhoods, remaking the campus into a superblock framed by a cordon sanitaire. The bulldozed sites served for decades as parking lots for the commuting university staff. In the words of Inga Saffron, the architectural critic of the Philadelphia Inquirer: 'As Penn's campus grew more splendid it became an island of privilege in a sea of poverty. Penn effectively cordoned off its campus by erecting buildings that faced inward, going so far as to put the loading dock of Van Pelt Library on once-gracious Walnut Street. ${ }^{16}$

Judith Rodin's appointment as president of the university brought a period of re-examination culminating in the strategy called Penn Connects in 2006, which set out to realign the university with the needs of its immediate neighbours and the city of Philadelphia more broadly. The masterplan prepared by the Massachusetts-based Sasaki Associates broke the cordon around the campus by all means possible - by reopening streets, landscaping new public spaces, reorienting the building facades. And once again, proper doors were opened onto Walnut Street. In 2011 the Sasaki team updated the strategy into Penn Connects 2.0, a more far-reaching vision for 'Bridges of Connectivity' between the campus and the Schuylkill River, by expanding the university estate, while also enlarging the public realm of the city with parks and open spaces. Architectural guidelines have ensured that new buildings present active frontages onto the public thoroughfares and are designed as much for external as for campus

\footnotetext{
14 Kvan, 'Context', 4-5.

15 John L. Plunkett, Mark Frazier Lloyd, Becoming Penn: the Pragmatic American University 1950-2000 (Philadelphia: UPenn Press, 2015).

16 Inga Saffron, 'Changing Skyline: The ugly story behind Penn's bucolic urban campus', Philadelphia Inquirer, 27 November 2015
} 
viewing. The same philosophy runs through the work of the Sasaki Associates on other campuses around the world. A recent awardwinning example from the city of Monterrey, Mexico is the Tecnológico de Monterrey Urban Regeneration Plan of 2014. It features an entirely different context and players, but includes a recognisable narrative arc from defensive, security-driven enclave into extrovert partner, by regenerating its urban setting through spatial connectivity and practical collaboration.

Master plans for university campuses provide significant work for Sasaki's design team, and the same applies to other practices, such as Urban Strategies (based in Toronto), Venturi Scott Brown (Philadelphia), Aecom (London), BDP (Manchester), and Koetter Kim (Boston). Browsing the project details on their websites, we repeatedly encounter the same discourses. To mention just a few, there is the pioneering 1994 strategy enacted at the University of Minnesota to 'weave campuses into the existing fabric ... opening through streets to improve access, placing new housing units among classroom buildings, and reintegrating pedestrians, cars and light rail at street level'17; Yale University's Framework for Campus Planning of 2000 based on the premise that 'Yale should strive to mesh the borders and edges of the University campus with its surrounding neighbourhoods by reducing those barriers, whether physical or psychological, that prevent the blending of Yale and New Haven'; for example, in the low-rise, outward-facing premises of the Broadway retail district ${ }^{18}$. The University of Michigan Master Plan commissioned by President Lee Bollinger calls for the school 'to conceive of our Campus as a whole and consider its place in the larger Ann Arbor community'19; McMaster University's 2008 plan to merge with its context through gateways, facades, walkable pedestrian ways and 'university-community partnerships' aims to bring new faces onto the campus; MIT's strategy to reconnect the eastern end of its campus with the central business district of Cambridge, by reconfiguring a zone of parking lots into a perimeter of building blocks with a double

17 See: www.urbanstrategies.com/projects [accessed 24.04.2017].

18 Yale University: A Framework for Campus Planning (New Haven: Yale University, 2000), 149.

19 See: http://www.vsba.com/projects/university-of-michigan-campus-master-plan/ [accessed 24.04.2017]. 
aspect - outward to Kendall Green and inward to the refurbished landscape of the campus ${ }^{20}$.

Drawing parallels with the retail sector, transport planning and housing design, we can readily explain the shift of campus strategies in terms of a generic trend towards a New Urbanism or Neue Urbanität. But the interest in connectivity has particular relevance for universities. In the United States, it reflects their privileged taxexempt status and consequently their need to overtly demonstrate corporate engagement and responsibility. And universities everywhere have been affected by a changed understanding of the role of knowledge in economic performance. Macroeconomics is paying increasing attention to the contribution of agglomeration factors to regional variations in productivity. Conscious of global competition, cities have come to appreciate how universities can enhance their competitiveness. ${ }^{21}$ Embedding a university within a regional economy offers mutual benefits to researchers through spin-offs and commercial exploitation, and to businesses through access to the knowledge frontier. ${ }^{22}$ The economist Richard Florida has travelled the world preaching the doctrine of creative symbiosis between region and campus. ${ }^{23}$ The simultaneous revolution in information technology reinforces - perhaps paradoxically - the need for universities to be embedded in their local contexts, and (in web-parlance) 'sticky' in attracting and retaining talent. ${ }^{24}$ The more knowledge is globally networked, the greater the demand for faceto-face contact in sites of innovation. The knowledge economy is breaking down the conventional boundaries between the campus and the city. In new developments the two may be as intertwined as they were in the oldest urban universities. Thus, the current northwest urban extension of the city of Cambridge will be built on 150 hectares of a university-owned site. And it will combine up to 3,000 units of private housing with accommodations for key workers on the

20 See: http://www.mit.edu/mit2030/ [accessed 24.04.2017].

21 Paul Benneworth, Gert-Han Jospers, Urban Competitiveness in the Knowledge Economy: Universities as New Planning Animators (Oxford: Elsevier, 2007), 5.

22 John Goddard, Paul Vallance, The University and the City (London: Routledge for Regional Studies Association, 2013).

23 Richard Florida, 'Regions and Universities Together Can Foster a Creative Economy', Chronicle of Higher Education, 53 (4) (2006), 6.

24 Taylor, Future Campus, 7. 
university staff and post-graduate students (2,000 units), as well as academic buildings with R\&D space, start-ups and supporting social facilities. Additional retail/commercial units will provide a local centre. The main objective of AECOM, the master planner, has been to ensure that the university's needs are as integrated with city's needs in the new urban extension as well as in the historical core. ${ }^{25}$

\section{INTERNAL CONSOLIDATION}

The Zeitgeist poses a problem for out-of-town campuses developed at low densities in rural settings. A famous example is the Hönggerberg site of ETH, built in the 1960s as a spacious science park in the countryside outside Zürich. 'In common with many satellite science precincts built at this time, it suffered from its isolated location, unwelcoming open spaces and uninspiring buildings. It was a 9-am-to-5-pm commuter campus, overshadowed by fragmentation and remoteness. ${ }^{26}$ The solution was to urbanise Hönggerberg. The university hired the Dutch designer Kees Christiaanse to build up its empty spaces, bring in housing and shops, and transform the monolithic quasi-rural campus into a quasi-suburb, a process celebrated in the book Campus and the City: Urban Design for the Knowledge Society. The approach has been widely adopted - in the terminology of the French national Plan Université 2000, higher education used to pursue a 'logic of extension' - today's doctrine is a 'logic of densification'. ${ }^{27}$

The process of internal consolidation has an evident microeconomic basis. In the context of declining public subsidies and an intensifying global competition for students, faculty and research funds, universities must make more efficient use of their assets. Large plots consigned to grass or outdoor parking lots, teaching rooms empty during extended vacation periods, and staff offices that are barely occupied once a week provide obvious targets for responsible

25 Coulson, Roberts, Taylor, University Trends - Contemporary Campus Design, 170.

26 Ibidem, 202.

27 Towards the 21st Century: Facilities for Tertiary Education (Paris: OECD, 1998), 52. 
management. ${ }^{28}$ The business basis of campus consolidation has been well documented in the United States and elsewhere by the scholars David Perry and Wim Wiewel. ${ }^{29}$

While densification enlarges the stock of active land use and rentable floorspace, thereby boosting the financial bottom line, it also reflects another policy, the benefits of which are more cultural or psychological: the creation of urban space, Städtraum, in the voids between the buildings. Whereas $20^{\text {th }}$ century aesthetics favoured freestanding buildings in an open landscape, contemporary interventions have tended to fill the gaps, thereby creating a continuity of built-up form. As in traditional urban settings, attached buildings form walls of frontage along circulation routes, defining streets, squares, places. The process is often described as 'place-making'. As articulated by Brian Edwards in his standard text, 'enclosure, route, gateway, promenade and vista are essential qualities in campus place-making'. ${ }^{30}$

We can illustrate this shift in thinking based on the design history of the University of Manchester. Its 1967 Master Plan sought to create the ambience of an out-of-town campus at this city-centre university. The park was to be given a hard boundary with dual-carriageways around the edges, which were lined with buffer plantings. Inside this frame, $45 \%$ of the area was occupied by parking lots, the rest was laid out as an informal landscape of grass, shrubs and trees. Forty years on, the university's master plan prepared by Sir Terry Farrell in 2004 sought to eliminate the sense of a barrier around the edge of the campus and reconnect the campus to its urban setting. Surface carparks and informal grassy swards were reallocated as sites for intensive development that would restore the sense of a coherent system of solids and voids. Instead of the edgeless spaces of an informal landscape, the new public realm would consist of streets and squares with proper names, planted with street trees, framed by active building frontage.

28 Alexi Marmot, 'Managing the Campus', The Physical University: Contours of Space and Place in Higher Education, ed. by Paul Temple (London: Routledge, 2014), 58-71.

29 David C. Perry, Wim Wiewel, The University as Urban Developer (Washington DC: Lincoln Institute of Land Policy, 2005).

30 Brian Edwards, University Architecture (London: Spon, 2000); see also Richard P. Dober, Campus Design (New York: Wiley, 1992). 
The underlying concept here is to make the outdoor space of the campus as legible as the buildings that define it: in Gestalt terminology, solid and void should form a reversible figure-ground ${ }^{31}$. In a paper on 'Success and Failure in Campus Design in the PostWorld War II Era', Stefanos Polyzoides defines successful campus design as the 'figuration of the void'. ${ }^{32}$ The shaping of outdoor spaces, open to the sky, is as significant for the collective image of the university as new buildings are for their occupants: we can find this place-making motivation in the development of parking lots around the University of California at San Diego ${ }^{33}$; in the current extensive consolidation around the campus of the University of Texas at Austin; and in the long-term strategy of infill, consolidation and place-making within the immense estate of Stanford University, of which the former university architect David Neumann liked to say 'we are building a campus, but every building is campus-building - with building as a verb'. ${ }^{34}$

Two other factors reinforce the concern for place-making. One is climate change. The inclusion of carbon-mitigation in universities' performance measures provides fresh impetus to layouts that are compact, accessible and energy-efficient. Ideally, in the words of Brian Edwards, 'the university campus provides us with a glimpse into the sustainable future' ${ }^{35}$ But secondly, as is so often true in university history, the physical trend has an abstract epistemological basis. Today the frontiers of science and creativity in the university transcend the boundaries between disciplines. The most fertile knowledge environments are no longer cells of specialisation, but interstitial spaces where different specialisms come together. This too provides fresh impetus for shaping a physical public realm.

31 Michael Hebbert, 'Figure-Ground, History and Practice of a Planning Technique', Town Planning Review, 87 (6) (2016), 705-729.

32 Stefanos Polyzoides, 'Success and Failure in Campus Design in the Post-World War II Era', Designing the Campus of Tomorrow: The Legacy of the Hearst Architectural Plan, Present and Future. Symposium, Berkeley Art Museum, 10 February 2000. Web published: http://sunsite. berkeley.edu/uchistory/archives [accessed 24.04.2017].

33 John Punter, Design Guidelines in American Cities (Liverpool: Liverpool University Press, 1999), 181.

34 Andrew Blum, 'David Neuman: Planning Utopias Where Campus is King', Architectural Record, 192 (1) (2004), 208; and see Neuman in Designing the Campus of Tomorrow (Berkeley Art Museum).

35 Edwards, University Architecture, v. 
The implications can be demonstrated with an example from the intensely competitive environment of the pharmaceutical industry. When Ciba-Geigy and Sandoz merged to form the pharmaceutical giant Novartis, their 51-acre St Johann factory in Basle was redeveloped as a research facility. Ignoring all the precepts of science park design, the site was configured as a high-density set of urban blocks, based on a grid of deep, narrow streets scaled to resemble a historic urban core. The 2001 masterplan by Vittorio Magnago Lumpagnani laid out an extension of the Basle street grid with trees, standard paving and lighting details to match. Cafes were also included to encourage everyday interaction between workers from different divisions of the company. Buildings were commissioned from leading architects and given a brief that protected the integrity of the street. The entire project aspired to be as different as possible from those low-density campus settings that Michel Foucault grouped with shopping malls and airports under the damning category of 'heterotopias'. In the words of Richard Ingersoll: 'The openness, transparency and variety found in the nascent little city of Novartis Ville give it a critical advantage as a place of creativity. By fostering a contrast between the utilitarian repetition of the urban block type with the hedonistic variety of their contents and cladding, the planners have generated a dynamic scenario that promises to supplant the heterotopian beginnings of a corporate campus with an increasingly urban way of life. ${ }^{36}$

Only the perimeter fence reveals that the so-called Novartis Ville is not a town at all but the high-security research division of a corporation. It is nevertheless a relevant precedent for universities, hence its place in Kerstin Hoeger's collection Urban Design for the Knowledge Society.

\section{MIXING USES}

Focusing finally on building scale, what are the architectural implications of the new campus urbanism? The answer can be found in the characteristic building types of the traditional city: built to the

36 Richard Ingersoll, 'From the Confinement of Heterotopia to the Urbanity of Novertis Ville', Novartis Campus: A Contemporary Work Environment: Premises, Elements, Perspectives, ed. by Jacqueline Burckhardt, Martine Francotte, Vittorio Magnago Lampugnani, et al. (Ostfildern: Hatje Cantz Verlag, 2009), 257-265. 
edges of plots, addressing the public thoroughfare and courtyards or gardens within; vertically layered with active frontages facing the street; above all, buildings with a mixture of uses above and below. The discrete building types of the last century have been replaced by hybrids, designed for multiple functions and versatility over time. In the era of ubiquitous mobile computing, the singlefunction library is merging with the café, the corridor, the common room, the seminar, and computer cluster into 'learning commons'. A blurring of typologies reflects real-world changes in work patterns and learning behaviour. Marketing strategists report an observable shift in the cultural preferences of the so-called $Y$ and Millennial generations (born from 1977 and 2000 respectively) towards urban lifestyles and consumption patterns: preferences for walking or cycling rather than commuting by private car; daily routines that dissolve the conventional boundaries between living and working; a social geography that has taken the coffee house back to its $18^{\text {th }}$ century origins as a place to exchange ideas and do business.

The shift has radical implications for university architecture. A seminal example of the new hybridity is the Ray and Maria Stata Center for Computer, Information and Intelligence Science at MIT. ${ }^{37}$ Designed by Frank Gehry and opened in 2005, the building reverses the traditional relationship between offices and corridors. Circulation space predominates, with informal benches and chalkboards at every turn, to encourage chance encounters and the jotting down of inspirations. A more conventional-looking example, also from MIT, is University Park, a 27-acre site on Massachusetts Avenue, formerly occupied at low density by light industry, but redeveloped in 2005 as an incubator zone for bio-technology and other hi-tech industries. The design by Koetter Kim \& Associates created 2.5 million square feet of mixed development in urban blocks aligned to the neighbouring street grid. The buildings combine R\&D labs with offices, apartments, a conference centre and hotel. The scheme is currently (in 2016) being extended to include retail space on Massachusetts Avenue.

37 'Special Issue: New University Environments', $A \& U, 2$ (413) (2005), 7-119. 


\section{CONCLUSION}

I started this lecture with a disclaimer: it is rash to generalise about trends in campus design. Conventional suburban landscaped campuses are still being created in large numbers, especially in China where the greatest expansion of higher education is now underway. Even where campus master plans proclaim a new-found urbanity, these aspirational documents may be ignored during implementation or overridden when a new university president or campus manager is appointed. ${ }^{38}$ Although we should qualify the generalisation, the historical trend is clear. Knowledge is no longer an elite activity requiring seclusion from the masses. It should be distributed as widely as possible throughout the working population. The city-campus dichotomy has been reversed. In the words of Janne Corneil and Philip Parsons, of Sasaki Associates: 'Today the boundary between the university and the city must become porous, or better, non-existent. In a healthy knowledge society, the university becomes the city and the city becomes the university. ${ }^{39}$

In the previous century we saw how universities migrated out-oftown to seek a better future in the open landscape. Let me end with two brief, contrasting examples of recent moves in the other direction.

First, Arizona State University, the epitome of an U.S. Land Grant campus, which is expanding into the vibrant areas of bio-science and informatics, realised that its ability to attract young talent would be compromised if interdisciplinary frontier initiatives, such as the Translational Genomics Research Institute, were located in the conventional out-of-town environment of the main campus. Jon Jerde was commissioned to design a new campus in the mixed area just north of the central business district of the city of Phoenix: an 'emerging knowledge hub' with 15,000 students and 3,800 employees. Its buildings are street-based and mixed-use, with rentable Class B office space for commercial tenants to create 'a synergistic force in downtown Phoenix'. At its launch in October 2004, Mayor Phil Gordon spelled out the economic significance of the Downtown Campus in graphic terms: 'Good paying jobs occur where educated

38 Edwards, University Architecture, 3.

39 Janne Corneil, Philip Parsons, 'The Contribution of Campus Design to the Knowledge Society: An International Perspective', Campus and the City - Urban Design for the Knowledge Society, ed. by Kerstin Hoeger, Kees Christiaanse (Zürich: GTA Verlag, 2007), 114-127. 
people migrate. The long-range impact of educational opportunities in downtown Phoenix will do more for increasing the economic wealth of Phoenix residents than any other single economic development initiative being contemplated. Ever. That's where our plan and our vision are taking us - and $\$ 50$ billion is what they're bringing us. Boy, do I love education!'40

Finally, let's return to France, whose universities conspicuously led the centrifugal shift in the 1960s. Thirty years on they were leading 'the return', often bringing new life and activity to derelict buildings. ${ }^{41}$ Examples could be drawn from Lille, Grenoble and Lyon, but the most conspicuous is the relocation of the Universite Diderot (Paris VII) from its out-of-town campus to the former industrial and transport zone behind the Gare Austerlitz on the left bank of the Seine. Planned by Christian de Portzamparc, the Quartier Masséna is a new district constructed partly on derelict railway lands and partly on a deck over the operational tracks. The street-based buildings of Paris VII are dispersed among the houses, shops and business of the quarter. At its heart, the Université Diderot proclaims itself 'to be a campus immersed in the city, immersed in life' - une université citoyenne. In such a setting we can truly say that our narrative has come full circle: knowledge has returned to its urban roots.

Michael Hebbert: From Campus Landscapes to Knowledge Quarters: How Learning Returned to Its Urban Roots

KEYWORDS: UNIVERSITY CAMPUS; URBAN SPACE AND ARCHITECTURE; MODERN UNIVERSITY LANDSCAPE; $20^{\text {TH }}$ CENTURY ARChitecture; NeW URbanisM

Michael Hebbert is Professor Emeritus at the University of Manchester and University College London. He pursued a PhD with the late Professor Sir Peter Hall at the University of Reading. His

40 MAGAZine, 9 (4) (November 2004), 3.

41 Towards the 21st Century: Facilities for Tertiary Education, 46. 
main research fields are the history of town planning, metropolitan governance, urban design and the street environment and urban climatology, especially in the context of London and Manchester. After many years directing the interdepartmental programme in regional and urban planning at the London School of Economics, he was appointed as the Chair of Town Planning in Manchester in 1994 and to UCL's Bartlett School in 2012. Author of London More by Fortune and Design (1998) and more than a hundred scientific papers, he has wide-ranging research interests in the history, purpose and method of urban design, and has served as editor of both Progress in Planning (Elsevier) and Planning Perspectives (Routledge). 


